\title{
Klasik Arap Edebiyatında Yahudi Şairlere Düzenlenen Suikastlar
}

\author{
Esat Ayyıldız ${ }^{\mathrm{a}, \mathrm{b}}$
}

Özet

Arap kabilelerinin kendilerine has bir şiir literatürü geliştirmeye başladığı zamanlardan beri, Yahudi aşiretleri de onların arasında yaşamış ve onların dilinde konuşmuştur. Günümüze ulaşan beyitlerden çıkarım yapmak gerekirse, Arabistan'daki Yahudi kabilelerinin kasidelerinin de hemen hemen Arap şiiri kadar eski olduğunu söylemek mümkün olacaktır. Yahudi şairler, İslam'ın ilk yıllarında da önemli bir rol üstlenmişlerdir. İslam'ın merkezî şahsiyeti olan Hz. Muhammed, Yahudi şairlerle pek çok ilişki kurmuştur. Ancak Yahudi liderler Hz. Muhammed'e karşı giriştikleri muhalefetlerini sürdürmüş, meşhur şairleri de $\mathrm{Hz}$. Peygambere ve arkadaşlarına karşı bir propaganda kampanyası başlatmıştır. Medine'nin Yahudi şairleri, kentin Müslümanlarını kendi neseplerinden olmayan bir dinî lidere tabi oldukları gerekçesiyle tahkir etmeleriyle maruftur. Bu yüzden söz konusu şairler, yeni filizlenmekte olan İslam'ın en bariz düşmanları haline gelmişlerdir. İslam karşıtı propagandalarının neticesinde, $\mathrm{Hz}$. Muhammed onların katlini buyuracaktır. Çünkü bu şairler, İslam'ı kabul eden ve Hz. Peygamberle ittifak kuran yerel halkı açıkça aşağılamış, hatta Hz. Peygamber için suikast çağrısında bulunmuşlardır.
Anahtar Kelimeler

Yahudi-Arap Edebiyatı

Klasik Arap Edebiyatı

Suikasta Uğramış Yahudi Şairler

Ebû Râfi' Sellâm b. Ebî'l-Hukayk

Makale Hakkında

Geliş Tarihi: 22.10.2019

Kabul Tarihi: 12.10 .2020

Doi: 10.18026/cbayarsos.635935

\section{The Assassinations of the Jewish Poets In Classical Arabic Literature}

\section{Abstract}

From the time that the Arabian tribes commenced to develop a poetic literature of their own, Jewish clans lived among them and spoke their language. The qasidas of the Jewish tribes of Arabia, to judge from the verses handed down, must be about as old as Arabic poetry. The Jewish poets played a significant role in the first years of Islam. Prophet Muhammad, the central figure of Islam, had many contacts with Jewish poets. But the Jewish leaders continued their resistance to Muhammad and their famous poets began a propaganda campaign against the prophet and his friends. The Jewish poets of Medina were known for insulting the Muslims of the city for obeying a religious leader not of their own kin. Thus they became the most significant political enemies of the nascent Islam. As a result of the anti-Islamic propaganda, Muhammad ordered to kill them because they composed poems that publicly ridiculed the local people who converted to Islam and allied with the prophet, calling for his assassination.
Keywords

Judæo-Arabic Literature

Classical Arabic Literature

Assassinated Jewish Poets

Abu Râfi' Sallâm b. Abî'l-

Huqayq

About Article

Received: 21.10.2019

Accepted: 12.10.2020

Doi: 10.18026/cbayarsos.635935

a İletişim Yazarı: esatayyildiz@hotmail.com.

b Dr. Öğr. Üyesi, Kafkas Üniversitesi, Fen Edebiyat Fakültesi, Doğu Dilleri ve Edebiyatları Bölümü, Arap Dili ve Edebiyatı Anabilim Dalı, Kars, ORCID ID: 0000-0001-8067-7780 


\section{Giriş}

Orta Doğu'nun en kadim ve en köklü medeniyetlerinden olan Yahudi topluluğu, tarih boyunca karşılaştıkları baskı ve zulümlerden kurtulmak amacıyla dünyanın pek çok köşesine seyahat etmiş, keşfettikleri yeni coğrafyalara kapsamlı gelenek ve düşünce biçimlerini de taşımış ve bu süreçte Arabistan Yarımadası'nı da bir süreliğine yurt edinmişlerdir. Bu kıymetli konuklar ve yanlarında getirdikleri eşsiz diyanet anlayışı, Arap medeniyetinin gelişmesi için de ilham kaynağı olmuş, çok geçmeden tektanrıcıllk fikri, soyut düşünme becerileri, devletleşme kültürü ve uygarlaşma yolundaki diğer pek çok kavram, iptidai Arap kabileleri tarafından inanılmaz bir hızla benimsenmiştir. Arabistan'ın uygarlaştırılması sürecinde, bölgenin en seçkin kabilesi olan Kureyşs'in elitizminin ve pek çok deha çıartabilme potansiyelinin, Yahudiler tarafından tutuşturulan edebiyat ve medeniyet kıvılcımlarını devasa bir aleve dönüştürdüğü belirtilmelidir.

İslam öncesi tarihine, geleneklerine ve edebiyat faaliyetlerine baktığımızda, Yahudilerle Arap kabileleri arasında sıkı ilişkiler geliştirildiği ve bu kadim Sâmî yurdunda enfes bir kültür sentezinin meydana getirildiği gözlemlenmektedir. Dinî gelenek ve inançlarını korumakla birlikte, Yahudilerin süreç içerisinde tamamen Araplaştığı, Arap dilini benimseyerek Arap şiirine önemli katkılarda bulunduğu herkesin malumudur. Örneğin; Yahudi nazım ustası Semev'el b. 'Âdiyâ el-Ezdî (ö. H.Ö.65/560 [?]), erken dönem şairleri arasında adını duyurmayı başaracak, Arabistan'da köklü bir Yahudi şiir geleneğinin yeşermesinde belirgin bir mihenk taşı olacaktır (Sezgin, 1975: 249-250). İslam öncesindeki saygın Yahudi şairlerinin, Hz. Muhammed tarafından da itibar gördüğüne şüphe yoktur. Çünkü Hz. Muhammed'in ilerleyen yıllarda, Semev'el'in torunu olan Șafiyye bint Ḥyey (ö. 50/670 [?]) ile evlendiği bilinmektedir (el-Cemîl, 1422/2002: 40). Söz konusu Yahudi toplulukları İbraniceyle alakadar olmayı terk etmemekle beraber, şiirsel ürünlerinde Arapçadan asla şaşmayacaklardır. Çünkü erken dönem Arap siyasetinde söz sahibi olabilmek için, şiir sanatında uzmanlaşmış olmak yahut bu sanatta uzmanlaşmış kişilere maddi olanaklar sağlayarak kendi saflarına katabilmek temel bir gereksinimdir. Yahudiler edebiyat ve filoloji konusunda son derece mahir kişilerdir. Dolayısıyla çıkardıkları şairler, Arapçada hızla uzmanlaşacak, çok geçmeden yerli komşularıyla şiir atışmalarına girişebilecek kadar ilerleme kaydedecektir.

\section{İslamiyet'in Doğuşuyla Yahudi Şiirinin İslam Karşıtı Propaganda Kampanyasına Dönüştürülmesi ve Suikast Gerekçeleri}

Yarımadada hayat hem Yahudiler hem de Araplar için alışıldık seyrinde sürüp giderken, Yahudi şairlerin edebiyat sahasında gösterdikleri mevcudiyet de günlük ritmin monotonluğuna adapte olmuş durumdadır. Ancak bu alışıldık düzen fazla uzun sürmeyecektir. Çünkü Hz. Muhammed'in Mekke'deki baskılardan kurtulmak için Medine'ye hicret etmesiyle, Yahudi kabileleri putperest Araplarla kurdukları ikili ilişkileri devam ettiremedikleri yeni bir dinle karşı karşıya kalacaktır. İslam, Arap Paganizmine kıyasla Museviliğe çok daha yakın olmasına rağmen, İslamiyet'in yayılmacılık hususunda gösterdiği dinamizm, Yahudileri, özellikle de Yahudi şairlerini fazlasıly rahatsız edecektir. Yahudilerin bu dönemde nazmettiği şiirler incelendiğinde, onların İslam'ın getirdiği yeni yaşam biçimlerinden hoşlanmadığı, bu gelişmelerin onlarca yıldır sürdürüle gelen siyasî dengeleri sarsacağını düşündüğü ve eski komşularının İslamiyet'i kabul etmesini istemediği açıkça gözlemlenmektedir (İbn Hişâm, 1375/1955: 635-637). Arap Yahudilerinin İslam karşıtlığı, başlangıçta resmî bir muhalefet biçimindeyken, şairlerin insanları kışkırtmasının 
da etkisiyle, hızlıca geri dönüşü olmayan bir düşmanlığa evrilecektir. Artık Yahudi şairler, Hz. Muhammed'in en azılı düşmanı haline gelmiş, onu ve ona destek veren tüm Müslümanları eleştirmeye başlamış ve zamanla bu eleştiriler yerini fahiş küfürlere ve iftiralara bırakmıştır. Hz. Peygamberin Yahudi şairlere vereceği karşılıksa tek boyutlu olmayacaktır.

Hz. Muhammed Yahudiler tarafından kendi aleyhinde yürütülen şiir propagandasına karşı tutarlı bir plan hazırlamış, eylemlerinin muhtemel sonuçlarını hesaplamış ve düşmanlarını etkisiz hale getirmek amacıyla geç kalmadan harekete geçmiştir. Aldığı tedbirlerin ilk adımı, Müslüman şairler tarafından nazmedilecek karşılık kasideleriyle, Yahudilerin eleştirel dizelerine misilleme yapılmasını sağlamaktır. Hz. Muhammed'in ikinci hamlesi ise, eleştirel şiirler söyleyen Yahudi şairlerinin etkisiz hale getirilmesidir. Bu amaç doğrultusunda, Yahudilere suikast düzenlemesi için görevlendirdiği, birkaç kişiden müteşekkil birlikler oluşturacaktır (İbn Hişâm, 1375/1955: 54-57, 637). Söz konusu uygulamalar, Medine ve çevresindeki tüm şiir muhalefetini çok geçmeden susturmayı başaracaktır. Hz. Muhammed'in Yahudi şairlere karşı yürüttüğü strateji, putperest Arapların safında yer alan muhalif şairlere yönelik yürütülen programın devamı niteliğindedir. Dolayısıyla suikastların etnik kaygılarla gerçekleştirilmediği, bilakis bu operasyonların İslam aleyhtarı tüm şairlere karşı benzer şekilde uygulandığı özellikle belirtilmelidir.

Yahudilerin bu süreçte nazmettiği yergilerden günümüze ulaşan örnek sayısı pek azıdır. Hatta bazen bir şairden geriye kalan tüm miras, birkaç beyti geçmemektedir. Yine de bu rivayetler, doğru şekilde ele alındığında, araştırmacıyı Yahudi şiirinin eğilimlerine yönelik çarpıcı çıkarımlara ulaştıracak kadar ümit uyandırıcıdır. Örnekler incelendiğinde, söz konusu şiirlerin pek çoğunun hakaret içerikli olduğu, hatta Müslümanların ırzını hedef alan iğnelemeler ihtiva ettiği görülecektir (eț-Ṭaberî, t.y.: 488; ez-Znehebî, 1410/1990: 159-160). Nispeten daha zararsız görünen kasidelerin yergiselliğinin aşırılığını anlamak içinse, İslam öncesi Arap yergisinin eğilimlerinden haberdar olmak şarttır. Yahudi şairlere karşı düzenlenen operasyonların iç yüzünü aydınlatmak isteyen araştırmacı, bunu ancak edebiyat disiplinin rehberliğinde gerçekleştirebilecektir.

Kasidelere ve bu kasidelerin ardından gerçekleştirilen operasyonların seyrine tarafsız bir bakış açısıyla yaklaşmak, bilimin temel prensibidir. Oryantalizm çalışmaları, kadim doğu edebiyatlarının aydınlatılmasında son derece etkili olmuştur. Ancak bazen şarkiyatçıların İslamofobinin aktifleştirilmesinde önemli etkilerinin olduğu unutulmamalıdır (Büyüktopçu \& Gündoğdu, 2019: 94). Spekülasyonlara son derece elverişli bir konu olan "Yahudi şairlerin öldürülmesi" meselesi, ancak modern bilimin ışığında çözülebilecek bir sorundur. Örneğin; beş çocuk annesi olan 'Așmâ' bint Mervân (ö. 2/624)'ın çocuklarının yanında öldürülmesi, günümüzde bile İslam karşıtları tarafından gündeme getirilen konuların başında gelmektedir. Ancak 'Așmâ'nın insanları Hz. Muhammed'e suikast düzenlemeleri için kışkırtmaya çalıştığı dizelerini tahlil masasına koymadan, çocuklu bir kadının neden "sadece şiir söylediği" gerekçesiyle öldürülmüş olabileceğini anlamsızca tartışmak mantığa aykırı olacaktır (İbn Hişâm, 1375/1955: 637). Durumun açı̆̆a kavuşturulması amacıyla, dönemin öldürülen Yahudi şairlerinin kasideleri, akademik bir perspektiften sistematik bir biçimde ele alınmalıdır. Çünkü bunun gibi tartışmalı konularda, en doğru yol gösterici bilimdir. 


\section{Suikastla Sonuçlanan Kasidelerdeki Temel Eğilimler}

Yahudi şairlerin kasidelerinde dikkat çeken ilk nokta, söz konusu şiirlerin, klasik Arap edebiyatının fazla aşina olmadığı bir aşırılığa doğru, muazzam bir süratle sürüklenmiş olduğu gerçeğidir. Öldürülen her Yahudi şairin ardından, geride kalan dostları, arkadaşlarının yarım bıraktığı işin bayraktarlığını üstlenmektedir. Fakat öldürülen müttefiklerinin yasını tutan acılı Yahudiler, Hz. Muhammed'in aleyhinde nazmettikleri yeni kasidelerinde, muhalefetlerinin şiddetini tedrici olarak arttırmaktan da kendilerini alıkoyamamışlardır. Üstelik bunu yaparken hedef alınacaklarının gayet bilincindedirler. Çünkü gelinen en aşırı noktada, şairler Hz. Muhammed'in ailesine, hatta ailesindeki hanımlara dahi dil uzatmaya cüret etmişlerdir. Elbette Müslüman kadınların hedef alınmasının, dönemin şartlarında ne denli tehlikeli bir faaliyet olabileceği aşikârdır. Malum olduğu üzere, eski Arap ahlak anlayışı, bu tarz aşağılayıcı eylemlere karşı sessiz kalınmamasını öğütlemektedir. Tarih boyunca öngörülü ve tedbirli karakterleriyle şöhret kazanan Yahudilerin, böylesine ihtiyatsız girişimlerde bulunmuş olması, ziyadesiyle anlaşılmazdır. Büyük doğubilimci David Samuel Margoliouth (ö. 1940), bu konudaki şaşkınlığını dile getiren yazarların başında gelmektedir (Morgoliouth, 2003: 109). Yahudi şairlerin akıl almaz cesareti göz önünde bulundurulduğunda, bu enteresan durumun garabeti ne kadar vurgulansa da azdır. Öte yandan Yahudi şiirindeki eleştirel eğilimlerin ilk başlarda daha seviyeli olduğuna kuşku yoktur. Dönemin şiirlerine kronolojik bir perspektiften bakıldığında, bu durum açıkça gözlemlenebilmektedir.

Örneğin; Ebû 'Afek (ö.624 [?])'in Hz. Muhammed'i hedef aldığı kasidesi, bu bağlamda başlangıç noktası olarak mütalaa edilebilir. Hem kendisinin hem de kendisinden sonraki Yahudi şairlerinin öldürülmesiyle sonuçlanacak suikastlar silsilesi, bu kasidenin ardından vuku bulacaktır. Ebû 'Afek'in dizeleri, ölümünün ardından nazmedilen Yahudi şiirleriyle kıyaslandığında, kesinlikle çok daha hafif bir eleştirel düzlemde sınıflandırılabilecek niteliktedir (İbn Hişâm, 1375/1955: 635-636). Ancak bu yargıdan, şiirin yergiselliğinin az olduğu sonucu çıkartılmamalıdır. Çünkü Ebû 'Afek'in dizelerinde olduğu gibi, erdemli sayılan birisinin, yerilen kişinin karşısında yüceltilmesi, İslam öncesi Arap edebiyatında hafife alınabilecek bir eleştiri metodu değildir. Dönemin edebiyat geleneklerinde, ortak yargılarla oluşturulmuş, ancak adı konmamış kurallar bulunmaktadır. Kabile resmiyeti çerçevesinde belirlenen standartlara göre, formel bir yerginin en ağır şekli, herhangi birisiyle kıyaslanmak ve ondan daha aşağı tutulmaktır. Ebû 'Afek, beyitlerinde Hz. Muhammed ile Yahudi Kralı Tubba' Es'ad Ebû Kerib el-Ḥimyerî (Hüküm: 390-420 [?])'yi kıyaslayarak, resmiyet çerçevesinde nazmedebileceği en ağır hicviyeyi söylemiş bulunmaktadır (İbn Hişâm, 1375/1955: 635-636). Öte yandan kasidesinin İslam öncesi yergicilik geleneklerinin resmiyet çerçevesini aşmadığı aşikârdır. Ebû 'Afek' in kasidesindeki gibi formel eleştirinin en aşırı hali olarak değerlendirilen "kıyaslama şiirlerinin", İslam öncesinde bir şekilde tolere edilebildiği itiraf edilmelidir. Ancak eski Arapların bu gibi durumlarda daha müsamahakâr olmalarının nedeni, muhtemelen politik açıdan yeterince güçlü olmamalarından ve kan davalarından çekinmelerinden kaynaklanmaktadır. Oysa inancını bütün dünyaya yaymak için çıtı̆̆ 1 zorlu yolda, Hz. Muhammed'in korkuya ayıracak vakti yoktur. Karşılaştığ problemlere bulduğu çözümler, en hızlı sonucu hedefleyen pratik uygulamalardır. Ayrıca içinde bulunduğu siyasî ortam, tamamıyla din kavramı üzerinden şekillendiğinden, mevcut konjonktür, İslam öncesinin sosyo-politik yapısından büyük ölçüde farklılaşmış durumdadır. Dolayısıyla Hz. Muhammed tarafından, Yahudi kabilelerinin askerî gücünün İslam karşısında fazla dayanamayacağının ön görülmüş olması ve dinî savunma 
mekanizmalarının geliştirilmesi, eskinin mecburiyetleriyle biçimlendirilmiş olan hoşgörü sınırlarının daha dar hudutlara çekilmesiyle sonuçlanmışa benzemektedir.

Garip şekilde, Yahudilere yönelik suikastların muhtemel bir diğer nedeni, dönem insanlarının metafizik olgulara karşı beslediği derin inanışlardan kaynaklanıyor olabilir. Arap şiirinin büyücülük ve cincilik kültüyle ilişkilendirildiği malumdur (Mevsû‘ atu'ş-Şurûk, 1994: 306). Araplar tarafından, yergi kasidelerinin kötü niyetli "şair şeytanları" tarafından ilham edildiğine ve bu kötü ruhların yerilen kişi üzerinde olumsuz etkiler bırakabileceğine inanılmaktadır. Söz konusu hurafeler, dönemin Arapları arasında son derece yaygındır. Öte yandan, şiir geleneklerinde karşımıza çıkan bazı figürlerin hakikaten de büyücülük kültüyle yakından ilişkili olduğu aşikârdır (van Vloten, 1893: 186). Özellikle Yahudilerin o dönemde büyücülük sanatında uzmanlaştıklarının varsayıldığı göz önünde bulundurulduğunda, bu tezin ne denli isabetli olduğu daha da açıklık kazanacaktır. Hz. Muhammed'in şiirsel yergiler söyleyen Yahudilerin infazına hükmetmesinde, muhtemelen bu inançların azımsanamayacak bir rolü vardır. Nitekim hoşgörülülüğüyle tanınan Hz. Muhammed tarafından, muhalifleri af dileyerek İslam'ı kabul etmedikçe, eleştirel şiirlerin tolere edilmediği gözlemlenmektedir. Dolayısıyla hicvin aşkın bir sanat olarak değerlendirilmesi, Yahudi suikastlarında etkili olmuş olmalıdır (Wensinck, 1908: 152). Hz. Peygamberin emrettiği suikast eylemlerinin, Musevilikle veya Yahudilerle ilişkisinin olmadığı bilhassa belirtilmelidir. Çünkü o dönemde Hz. Muhammed, kendi aleyhinde şiir söyleyen şairler için, kim olduğuna yahut etnik kökenine bakmaksızın, ölüm fermanı vermeye başlamıştır. İslam'ın ve Hz. Peygamberin sosyal statüsünün korunması, suikastların temel amaçlardandır.

Hz. Muhammed'i resmiyet çerçevesinde eleştiren Ebû 'Afek'in öldürülmesinin ardından, geride kalan Yahudiler artık bu sınırları bir tarafa bırakacak, kasidelerinde adi sövgülere, iftiralara ve manipülatif kışkırtmalara yer vermekten çekinmeyecektir. Nitekim artık şiirin mahiyeti ve eleştirel seviyesi ne olursa olsun, Hz. Muhammed'i hedef alanların direkt olarak öldürüleceği anlaşılmış durumdadır. Dolayısıyla Ebû 'Afek'in öldürülmesinden sonraki süreçte, protest şairlik anlayışını benimseyen Yahudilerin, şiirlerindeki seviyeyi korumaya özen göstermeleri için herhangi bir nedenleri kalmayacaktır. Çünkü malum olduğu üzere, şiirlerin aşırılık seviyesinin belirli bir sınırın altında tutulmasının tek sebebi, hedef alınan kişilerin misillemesinden çekinilmesidir. Oysa şairler artık şiirleri ister fahiş isterse formel bir eleştiri olmuş olsun, benzer bir suikastla cezalandırılacaklarının bilincindedir. Öte yandan Hz. Muhammed'in, aşırılaşma ivmesine karşı aynı suikast programını devam ettirmesi, yükselen tansiyonun İslam cephesinde fazla hissedilmemesini sağlayacaktır. Hatta bu operasyonlar, İslam'ın kazandığı politik ivmeyi destekleyen bir hamleye dönüştürülecektir.

Ebû 'Afek'in öldürülmesinin akabinde, maktulün kasidesinden çok daha ağır bir dille nazmedilmiş olan kışkırtıcı dizeleriyle adını duyuran 'Așmâ' bint Mervân, Yahudi şiirinin aşırılaşmasındaki ikinci evre olarak değerlendirilebilir. 'Așmâ' söz konusu kasidesinde, Enșâr'ın mensup olduğu kabilelere, diğer bir deyişle Hz. Muhammed'in Medine'deki dostlarına, fahiş kelimeler kullanarak açıkça sövmektedir. Onları dışarıdan gelen ve kendilerinden olmayan Hz. Muhammed'e biat ettikleri gerekçesiyle suçlamaktadır. Ayrıca bu kasidede, Medineli Müslümanların, komşularının öldürülmesini umursamadıklarını ve Hz. Muhammed'den gelecek menfaatlerin peşine düştüklerini dile getirilerek, Enșâr'ın üyelerini eleştiri yağmuruna tutmaktadır. Tüm bunlardan daha tehlikeli olansa, 'Așmâ''nın Müslümanları Hz. Muhammed'e karşı suikast düzenlemeleri hususunda kışkırtmaya 
çalışmasıdır (İbn Hişâm, 1375/1955: 637). Elbette bu şiiri nazmederken, kasidesinin duyulduğu anda, ölüm fermanının verileceğini bilmektedir. Dolayısıyla kadının cesaretini garipsememek mümkün değildir. Belki de bu cesaretinin nedeni, Hz. Muhammed'e düzenlenmesi planlanan gizli bir suikastın gerçekleşme olasılığına inanmış olmasından kaynaklanmaktadır. Ancak ne 'Așmâ' ne de onun izinden giden diğerleri, eşine az rastlanır bir askerî deha olan Hz. Muhammed'in stratejik planlarını doğru değerlendirememelerinin sonucunu acı şekilde tecrübe etmekten kurtulamayacaklardır. Nitekim Hz. Peygamber, kadına düzenlenecek saldırının hiçbir tepki çekmeyeceğini önceden hesaplamış ve 'Așmâ'nın arkasında kimsenin durmayacağını arkadaşlarına bildirmiştir (İbn Hişâm, 1375/1955: 637). Hz. Muhammed'in bu isabetli öngörüsü, Yahudi kabilelerinin reaksiyonlarını ne denli iyi tahlil edebildiğinin en bariz göstergesidir. Kan davası sisteminin o dönemde halen devam ediyor olmasına rağmen, uyguladığ kökten sarsılacağından ve her şeyin arzulandığı seyirde ilerleyeceğinden son derece emindir. Yahudi şairlerin buradaki büyük talihsizliği, kendilerine rakip olarak seçtikleri kişinin, Arabistan'ın çıkartabileceği en yetenekli insan olmasıdır. Ancak o günlerde İslâmî hareketin global bir güç haline dönüşecek kadar ilerleyebileceğini tahmin edememiş olmaları kesinlikle doğaldır.

'Așmâ' bint Mervân'ın öldürülmesinin ardından, Yahudi şiirinin aşırılığı daha da artacaktır. Gelinen bu üçüncü evrede, Arabistan Yahudilerinin çıkardığı en uç şair, Ka'b b. el-Eşref (ö.3/624)'ten başkası değildir. Buraya kadar ismi geçen diğer şairlerde olduğu gibi, Ka'b'ın şairliği ve ölümü de oldukça kapsamlı bir konudur. Dolayısıyla bu şairlerin hepsi, müstakil bir çalışmada ele alınmayı fazlasıyla hak etmektedir. Ka'b ise, bu şairlerin arasında, hakkındaki verilerin daha çok olması hasebiyle, en kapsamlı çalışmaya konu olabilecek kişidir. Arabistan Yahudilerinin en aşırı hicviyelerini temsil eden kasideleri, nispeten daha geniş bir kapsama sahiptir. Şiirlerinde Müslümanların hanımlarını hedef alan kişi odur. Buna rağmen İslâmî siyer otoritelerinin, $\mathrm{Ka}^{\prime} \mathrm{b}^{\prime}$ ın kahramanlığından ve cesaretinden bahsetmekten çekinmediği gözlemlenmektedir. Kurulan kumpas sonucunda adım adım ölüme nasıl götürüldüğü ve güvendiği yakınları arasından seçilen suikastçılara karşı nasıl çetin bir mücadele verdiği, bu eserlerde detaylıca anlatılmaktadır (İbn Hişâm, 1375/1955: 5457).

Müslüman siyer tarihçileri tarafından, “Allah düşmanı" şeklinde nitelendirilen Ka’b'ın, yine aynı tarihçiler tarafından, yiğit birisi olarak sunulması ve ölümünün trajikleştirilmesi (İbn Hişâm, 1375/1955: 54-57), itiraf etmek gerekirse, son derece şaşırtıcıdır. Muhtemelen bu tercihin nedeni, yiğidi öldür hakkını yeme felsefesinden ziyade, söz konusu operasyonun icrasının zorluk derecesinin vurgulanması arzusudur. Çünkü benzer bir durum, Yahudilerin savaş̧̧ı şairi olarak tarih sahnesindeki yerini alan Merḥab b. el-Ḥâriş (ö. 7/628-629)'in kahramanlaştırılması sürecinde de karşımıza çıkmaktadır. Öte yandan Yahudi kabileleri, hakikaten de Mekkeli putperestlerden daha dişli rakipler olduklarını fazlasıyla ispatlamışlardır. Hatta Hz. Muhammed'e suikast girişiminde bulunarak meşhur zehirli eti tattıran Zeyneb bint el-Hâris_(ö. 7/628'den sonra), öldürülen Yahudi şairlerinden olan Merḥab b. el-Hâris ile Yâsir b. el-Hâris_ (ö. 7/628-629)'in yakın akrabasıdır. Hz. Muhammed etin zehrine fazla maruz kalmadan, zehirlendiğini fark ederek lokmasını yutmadan tükürecektir. Ancak buna rağmen, ilerleyen süreçte sıhhatinin yavaş yavaş bozulduğu ve birkaç yıl boyunca zehrin komplikasyonlarını vücudunda hissettiği bilinmektedir. Hatta onun söz konusu zehirlenme vakası nedeniyle hayatını kaybettiğini düşünenler dahi bulunmaktadır 
(Gülgün, 2013: 360). Bu bakımdan Yahudi şairlerin teşvik etmeye çalıştığg suikastlar, hiçbir zaman mutlak surette başarıya ulaşamamış olsa da, bütünüyle sonuçsuz kalmış da değildir.

\section{Klasik Arap Edebiyatındaki Suikast Anlatıları: Yahudi Şair Ebû Râfi' Sellâm b.

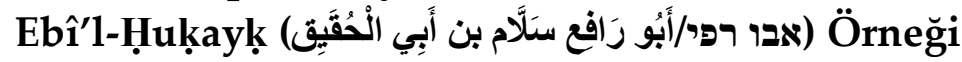

Hz. Muhammed'in yaşamını işleyen kadim eserlerde, Yahudi şairlerin durumunu ele alan bazı bölümlere rastlamak mümkündür. Bu kısımlar genellikle ele alınan şairin kimliğini açıklayarak söze başlamaktadır. Daha sonra -şayet biliniyorsa- şairin vurucu şiirlerinden birkaç beyit aktarılmakta, beyitlerin hatırlanamaması durumundaysa, bahsi geçen kişilerin İslam aleyhinde şiirlerinin bulunduğunun ifade edilmesiyle yetinilmektedir. Ardından $\mathrm{Hz}$. Peygamberin şiiri haber aldığında, şairin öldürülmesi için nasıl talimat verdiği anlatılmaktadır. Ölüm fermanları, bazen bizzat Hz. Muhammed'in inisiyatifiyle veriliyorken, bazen de onun takdirini kazanmak isteyen dostlarının, söz konusu şairlerin öldürülmesi için müsaade talep etmeleriyle onanmaktadır. Bu kısımların anlatımı tamamlandığında, rivayetler suikast için görevlendirilen kişilerin ön hazırlıklarından bahsetmekte ve nihayet operasyonun detaylarının aktarımına geçiş yapılmaktadır.

Yahudi şair Ebû Râfi' Sellâm b. Ebî'l-Ḥuḳayk (ö. 3/625 [?])’a düzenlenen suikast, bu konudaki tipik örneklerdendir. Ebû Râfi', Hz. Muhammed'in Medine'ye geldiği yıllarda, söz sahibi Yahudilerden birisi olarak tarih sahnesine çıkmaktadır. Şair, Hz. Muhammed'e muhalefetiyle tanınan ve politik olarak son derece aktif olan bir Yahudi ailesine mensuptur. İslam kuvvetlerine karşı savaşan Putperest Araplara, Ebû Râfi' tarafından destek sağlandığı ve bu uğurda onun büyük uğraşlar verdiği bilinmektedir. Şairin Arap edebiyatındaki ağırlığı, Hz. Muhammed'in aleyhinde şiirler nazmettiği gerekçesiyle öldürülmesi noktasında yoğunluk kazanmaktadır. Onun şairliği hakkında değerlendirme yapabilmemize imkân tanıyacak edebî materyaller, günümüze kadar ulaşmayı başaramamıştır. Zayıf bir ihtimalle, İslam tarihçileri, diğer Yahudi şairlerin öldürülmelerine neden olan kasidelere ayırdıkları hacmin yeterli geleceğini düşündüğünden, Ebû Râfi' 'nin şiirlerinin nasıl olduğunun, gelecek kuşaklar tarafından kolaylıkla tahmin edilebileceğini düşünmüş olabilir. Ancak bundan daha makul sayılabilecek başka bir teori, söz konusu şiirlerin tamamen unutulduğu yahut bu şiirlerin Müslümanlar tarafından hiçbir zaman tam manasıyla öğrenilemediği ihtimalidir. Dolayısıyla eleştirel dizelerin mevcudiyetinin haber alınmasına rağmen, siyer tarihçileri şairin eleştirel dizelerine hiçbir zaman ulaşamamış olmalıdır. Ebû Râfi''nin Medine'de ikamet etmiyor olması, bu son ihtimali daha da kuvvetlendirmektedir. Öte yandan şairin nasıl öldürüldüğ̈̈, klasik kayıtlarda ince detaylarıyla aktarılmaktadır. Harald Motzki'nin bu mevzuyu tüm ayrıntılarıyla incelediği, "The Murder of ibn Abil-Huqayq: On the Origin and Reliability of Some Maghazi-Reports" başlıklı bir kitap bölümü bulunmaktadır (Motzki, 2000: 170-239). Söz konusu eser, belirli bir Yahudi şairin nasıl öldürüldügünü ele alan, muhtemelen en kapsamlı yayındır. Bu anlatıların farklı otoriteler tarafından nasıl aktarıldığını görmek isteyen araştırmacıların, bahsi geçen kaynağa başvurması yeterli olacaktır.

Öncesinde öldürülen Yahudi şairlerin suikast anlatılarına kıyasla, İbn Ebî'l-Ḥuḳayk vakasında, dikkat çekici bir farklılık bulunmaktadır. Bu farklılık, suikast fikrini ateşleyen motivasyonun temel tetikleyicisidir. Bilindiği üzere, Ebû Râfi' suikastından önce, İslam'1 hedef alan kasideler nazmettiği gerekçesiyle Ka'b b. el-Eşref için, Evs Kabilesi aracılığıyla suikast tertiplenmiştir. Evs Kabilesi, Hazrec Kabilesinin İslam öncesindeki en büyük rakibidir. Dolayısıyla Hazrec'in üyeleri, eski rakipleri olan Evs'in gerisinde kalmamak 
amacıyla, Ka'b b. el-Eşref'in muadili olabilecek bir Yahudi şair arayışına girişmekte gecikmeyecektir. Hayber'de bulunan Sellâm b. Ebî'l-Ḥuḳayḳ akıllarına gelince, şaire suikast düzenlemek için Hz. Peygamberden izin isteyerek öldürme ruhsatı alacaklardır. Evs ve Hazrec kabilelerinin Hz. Peygamberin gözüne girmek amacıyla birbirleriyle yarışmaya başlamasının, İslam karşıtlarının etkisiz hale getirilmesinde son derece etkili olduğu gözlemlenmektedir. Sellâm'ın öldürülmesi, tamamen bu rekabetin sonuçlarından biridir (İbn Hişâm, 1375/1955: 273-275).

Dolayısıyla Sellâm'ın öldürülme nedeni, eleştirel kasidelerinden ziyade, kabile rekabetinin bir sonucudur. Siyer kaynaklarında Sellâm'ın öldürülmesine neden olan kasidelerin rivayet edilmemesi, bu teoriyi destekler niteliktedir. Öte yandan kaynaklar bu rekabeti ve suikastın detaylarını tafsilatlı şekilde aktarmaktadır. Rivayetlere göre, Hazrec kabilesine mensup olan Benû Seleme'den beş kişi, 'Abdullah b. 'Atîk'in liderliğinde, şairi öldürmek için Hayber'e gönderilmiştir. Kadınları ve çocukları öldürmemeleri hususunda, Hz. Peygamber'in bu gruba bilhassa talimat verdiği kaydedilmektedir. Sahabeler gece vakti Hayber'e geldiğinde, ihtiyaten civardaki tüm hanelerin kapılarını içeridekilerin üzerine kapatarak Sellâm'ın evine gidecektir. Ancak şairin odasına varan sahabelerin dikkat çekmeden içeri girmesi, kapıyı açacak kişiyi kandırabilmelerine bağlıdır. Şairin hanımı onlara seslenerek kim olduklarını sorduğunda, içeri girmek için izin isteyen suikastçılar, kadını kandırmakta hiç güçlük çekmeyecektir. Çünkü hedef alınan şairlerin öldürülmesinin sağlanması hususunda, Hz. Muhammed tarafından, suikastçlara yalan söyleme ruhsatının verildiği bilinmektedir. Grup üyeleri: "Biz yemek isteyen Araplarız." yanıtını vererek kadını kolayca kandıracak ve içeri hiçbir mukavemetle karşılaşmadan sizabilecektir (İbn Hişâm, 1375/1955: 273-275, 54-57).

Hedeflerine kolayca ulaşan sahabelerin, şairi öldürürken de fazla zorlanmadığı gözlemlenmektedir. Öte yandan şairin hanımı, doğal olarak suikastçılara mani olmak için elinden geleni yapmıştır. Bu yüzden, sahabelerden birisinin kadını öldürmek amacıyla hamle yapmaya kalktığı, ancak son anda Hz. Peygamber'in buyruğunu hatırlayarak kadına zarar vermekten geri durduğu kaydedilmektedir. Şairin öldürülmesinden ve öldüğünün teyit edilmesinden sonra, arkadaşlarından birinin düşerek yaralanmasına rağmen, sahabeler olay yerinden bir şekilde hep beraber kaçmayı başaracaktır. Suikastın çok karanlık bir yerde gerçekleştirilmiş olması dolayısıyla, şairi kimin öldürdügü hususunda anlaşmazlığa düşen Müslümanlar, Hz. Muhammed'in yanına ulaştıklarında durumu ona bildirecektir. Onların kılıçlarını inceleyerek şairi öldüren kişiyi tespit eden Hz. Peygamberin ilan ettiği kişi, Abdullah b. Uneys'tir (İbn Hişâm, 1375/1955: 273-275).

İbn İshak ve el-Vâkidî, Sellâm b. Ebî'l-Hukạaḳ’ın hangi tarihte öldürüldüğü hususunda farklı görüşlere sahiptir. el-Vâkidî hadiseyi, Hicretin dördüncü yılındaki Zû́̂'l-Hicce ayına tarihlendirmektedir. Ona göre şairin öldürülme nedeni, Benû Naḍ̂r seferindeki faaliyetleridir. İbn İshak ise, bunun tam aksine, şairin ölümünü Hendek vakasının hemen sonrasına tarihlendirmektedir. Ona göre suikastın nedeni, şairin Mekkelilerle birlik olarak Medine'ye düzenlenen saldırılara destek sağlamış olmasıdır (Faizer, 1996: 480-481). Sonuç itibarıla, Ebû Râfi'"nin öldürülüşünün $\mathrm{Ka}$ 'b b. el-Eşref suikastının çok sonrasında olamayacağını varsayarsak, ölüm tarihi olarak 3/625 yılına işaret etmek yanlış olmayacaktır (Ma'mar Ibn Rashid, 2014: 338). 


\section{Sonuç}

Hicret'ten sonrasındaki ilk birkaç sene, Arap dilinde ürün veren Yahudi şairler açısından önemli olaylara sahne olmuştur. Yahudi şiirinin bu süreçteki seyri, İslam öncesinin alışıldık rutinin dişına çıkmış ve Arabistan'daki Yahudi nazmının en etkili olduğu dönemi meydana getirmiştir. İslam-Yahudi karşıtlığı sürecinde yaşanan tatsızlıklar, yalnızca dönemin Arap Yahudilerinin hayatını değiştirmekle kalmamış, aynı zamanda modern Yahudi düşüncesi üzerinde de bir takım kalıcı etkiler bırakmıştır. Değişim talebinde olan İslamiyet'in karşısında, eskinin geleneklerini, alışıldık kabile ilişkilerini ve resmileştirilmiş siyasî ittifaklarını muhafaza etmeye çalışan Yahudi şairler, her zaman aktif politikanın tam merkezinde yer almışlardır. Elbette Yahudilerin siyaset sahasında gösterdikleri dinamizm ve üstlendikleri keskin muhalefet rolü, hızla erk sahibi olmaya başlayan rakiplerinin hiç de hoşuna gitmeyecektir. Şiir sahasında başlayan rekabet, fiziki boyuta taşmaya artık hiç olmadığı kadar yakındır. Hz. Muhammed, İslam kuvvetlerinin askerî gücünün yeterince olgunlaştığına kanaat getirdiğinde, kendi aleyhinde propaganda kampanyası başlatan tüm şairleri, özellikle de söz sahibi Yahudileri ekarte etmek için harekete geçer. Şiirsel saldırılara karşı geliştirdiği çözüm, muhalif şairlerin teker teker pusuya düşürülerek etkisiz hale getirilmesidir.

Hz. Muhammed'in başlattığı suikast programı, basit bir çözüm gibi görünmesine rağmen, kesinlikle ince bir stratejik arka plana sahiptir. Görünüşe göre, infaz emirlerini vermeden önce, planlanan eylemin tüm muhtemel sonuçlarını zihninde hesaplamakta ve muhalefetin olası reaksiyonlarını minimize etmek amacıyla, tayin edeceği suikastçıları etnik kökenlerini göz önünde bulundurarak seçmektedir. Çünkü öldürülen kişi ile suikastçların aynı etnisiteye mensup olması durumunda, kan davacılarının olayın peşine düşmeyeceğini düşünmektedir. Hakikaten de eşsiz dehasının öngördüğü şekilde, harfiyen işleyen planı, çok geçmeden Yahudi entelektüellerinin ateşli muhalefetini tamamıla ortadan kaldıracaktır. Öte yandan son Yahudi şairinin öldürülmesi, Arabistan'daki köklü Yahudi bilgeliğinin sona erdiği anlamına gelmemektedir. Museviliği, yanlarında taşıdıkları muazzam bilgi birikimleriyle terk ederek İslam'a geçen Abdullah b. Selâm (ö. 43/663-64) gibi önemli Yahudi hahamlarının, İslam'ın yayılmasında ve standartlaştırılmasında büyük katkılar sağladığı bilinmektedir (Fayda, 1988: 134-135). Böylesi zıtlıklar, Yahudilerin hem İslam'ın en belirgin muhalifleri, hem de en mühim destekçileri olduğunu gözler önüne sermesi açısından, son derece manidardır.

Muhalif Yahudi şiirinin, ilk suikastın gerçekleştiği günden, son şairin öldürülmesine kadarki süreçte gösterdiği aşırılaşma eğilimi, üzerinde durulması gereken bir mevzudur. Nitekim söz konusu şiirlerin, başlangıçta daha seviyeli bir dille nazmedildiği gözlemlenmektedir. Diğer bir deyişle, kabileler arasında, İslam öncesinde standartlaştırılmış olan resmiyet sinırları, Yahudilerin bu alandaki ilk şiirlerinde de hâlâ etkinliğini sürdürmektedir. Ne var ki formaliteye verilen önem, Hz. Muhammed'in kendisini veya dinini hedef alan tüm Yahudi şairleri, şiirlerinin eleştirel seviyesine bakılmaksızın, aynı cezaya tabi tutmasıyla geçerliliğini yitirecektir. Yahudilerin gösterdiği reaksiyon, şiirlerin eleştirel seviyesinin küfre, hatta iftiraya varacak derecede arttırılmasıdır. Şairlerin kendi canlarını hiçe sayması, hiç kuşkusuz ki, oldukça şaşırtıcıdır. Ancak tüm eleştirel şiirlerin hâlihazırda zaten aynı suikast emriyle cezalandırılacağı göz önünde bulundurulduğunda, bu büyük tehlikeyi göğüsleme cüretini gösterebilecek şahsiyetteki kişilerin, mevcut sınırların zorlanmasından da çekinmeyeceği açıktır. 
Sonuç itibarıyla, Yahudi şairlerin Hz. Muhammed'in hayatında önemli bir rol üstlendiği, Hz. Peygamberin Yahudi bilginlerini İslam safına katmak için büyük uğraşlar verdiği, ama Yahudilerin Museviliğe sıkı sıkıya bağlı kalmayı tercih ettiği, böylelikle de kısa zaman içerisinde iki kesimin birbirinin en azılı düşmanı haline geldiği söylenebilir. Yahudilerin, Hz. Muhammed tarafından, Arabistan'ın ve Arap kültürünün önemli bir parçası olarak görüldüğüne hiç kuşku yoktur. Öte yandan, pek çoğu şair olan Yahudi eşrafına karşı izlenilen politikaların iç yüzünü ve bunların nasıl sonuçlandırıldığını tam manasıyla anlamak mümkün görünmemektedir. Tarihî kayıtların yetersizliği kadar, Hz. Muhammed'in kendine has politikalarının girift yapısı da bunda etkilidir. Örneğin; kendisini hicvedenlere karşı ölüm fermanı veren Hz. Muhammed'in, kendisini zehirleyerek öldürmeye teşebbüs eden Yahudi Zeyneb'i bağışladığı yönünde rivayetler bulunmaktadır. Öte yandan Hz. Peygamberin büyük kayınpederlerinden birisi olan Semev'el b. 'Âdiyâ el-Ezdî, Arabistan'ın en meşhur Yahudi şairidir. İkili ilişkiler bir şekilde uygun zemine oturtulduğunda, köklü geçmişi takdir edilen Yahudi halklarının, Kureyş tarafından her zaman ayrıcalıklı bir konuma yerleştirildiği, bu geleneğin de Hz. Peygamber tarafından İslam dairesinde sürdürülmeye çalışıldığı açıktır. Yaşanan tatsız olaylar tarihin tozlu sayfalarındaki yerini aldığında, Arap toplumunun içerisinde kendisine yeniden yer bulabilen Yahudi bilgeliği, yeni kuşakların çalışmalarıyla, bu kez Endülüs gibi uzak diyarlarda tekrar yeşerebilecektir.

\section{Kaynakça}

Büyüktopçu, M. B. \& Gündoğdu, S. (2019). Alman karikatürleri örneğinde İslamofobi. Kafkas Üniversitesi Sosyal Bilimler Enstitüsü Dergisi, (Fuat Sezgin Özel Sayısı), 91-102.

el-Cemîl, M. (1422/2002). en-Nebî ve Yahûdu'l-Medîne. Riyad: Merkezu'l-Melik Fayșal li'l-Buhûs ve'd-Dirâsâti'lİslâmiyye.

Faizer, R. S. (1996). Muhammad and the Medinan Jews: A comparison of the texts of Ibn Ishaq's Kitab Sirat Rasul Allah with al-Waqidi's Kitab al-Maghazi. International Journal of Middle East Studies, 28 (4), 463-489.

Fayda, M. (1988). Abdullah b. Selâm. DİA. (Cilt. 1). İstanbul: Türkiye Diyanet Vakfı.

Gülgün, U. (2013). Zeyneb bint Hâris. DİA. (Cilt. 44). İstanbul: Türkiye Diyanet Vakfı.

İbn Hişâm. (1375/1955). es-Sîretu'n-nebevîyye. (2. bs., Cilt. 2). M. es-Saḳkâ \& İ. el-Ebyârî \& 'A. eş-Şelebî (haz.), Misır: Mustafa el-Bâbî el-Ḥalebî ve Evlâduhu.

Ma'mar Ibn Rashid. (2014). The expeditions: An early biography of Muhammad. S. W. Anthony (çev.), New York: New York University Press.

Mevsû'atu'ş-şurûk. (1994). (Cilt. 1). Kâhire: Dâru'ş-Şurûḳ.

Morgoliouth, D. S. (2003). İslamiyet öncesi Arap-İsrailoğulları ilişkileri. S. Ertüzün (çev.), İstanbul: Kaknüs Yayınları.

Motzki, H. (2000). The murder of Ibn Abil-Huqayq: On the origin and reliability of some maghazi-reports. H. Motzki (Ed.), The biography of Muhammad: The issue of the sources içinde (ss.170-239). Leiden: Brill.

Sezgin, F. (1975). Geschichte des arabischen Schrifttums. (Cilt. 2). Leiden: E. J. Brill.

eț-Ṭaberî, E. (t.y.). Târîhu't-Taberî. (2. bs., Cilt. 2). M. E. İbrahim (thk.), Kâhire: Dâru'1-Ma'ârif.

van Vloten, G. (1893). Dämonen, Geister und Zauber bei den alten Arabern: Mittheilungen aus Djâhitz' Kitâb alhaiwân. Wiener Zeitschrift für die Kunde des Morgenlandes, (7), 169-187.

Wensinck, A. J. (1908). Mohammed en de Joden te Medina. Leiden: E.J. Brill.

ez-ZZehebî, Ş. (1410/1990). Târîhu'l-İslâm ve vefeyâtu'l-meşâhîr ve'l-a'lâm. (2. bs., Cilt. 1). Ö. 'A. Tedmurî (thk.), Beyrut: Dâru'l-Kitâbi'l-'Arabî. 